\title{
Short-Term Treatment as Long-Term Prevention: Can Early Intervention Produce Legacy Effects?
}

\section{Citation}

Weisz, John R. 2014. “Short-Term Treatment as Long-Term Prevention: Can Early Intervention Produce Legacy Effects?" American Journal of Psychiatry 171, no. 6: 600-602.

\section{Published Version}

doi:10.1176/appi.ajp.2014.14030361

\section{Permanent link}

http://nrs.harvard.edu/urn-3:HUL.InstRepos:17219052

\section{Terms of Use}

This article was downloaded from Harvard University's DASH repository, and is made available under the terms and conditions applicable to Open Access Policy Articles, as set forth at http:// nrs.harvard.edu/urn-3:HUL.InstRepos:dash.current.terms-of-use\#OAP

\section{Share Your Story}

The Harvard community has made this article openly available.

Please share how this access benefits you. Submit a story.

Accessibility 
Word count for text: 1151

Word count including references: 1488

Number of references: 11

\begin{abstract}
Short-term Treatment as Long-term Prevention:
Can Early Intervention for Antisocial Behavior Produce Legacy Effects?

John R. Weisz, Ph.D.
\end{abstract}

Location of the work, and address for reprints. From the Department of Psychology, Faculty of Arts and Sciences, Harvard University.

Reprint requests should be addressed to John R. Weisz, Department of Psychology, William James Hall, Harvard University, 33 Kirkland Street, Cambridge, MA 02138. Email: john weisz@harvard.edu.

Disclosures. Dr. Weisz receives royalties for books related to youth psychopathology and psychotherapy. He has no competing interests. 
For much of the twentieth century, research cast doubt on prospects for preventing or treating antisocial behavior. But family-based research (e.g.,1) suggested that behavioral interventions to build parenting skill might reduce child conduct problems, and multiple parent training programs were developed and shown to be effective (e.g., 2,3,4; see 5 for other examples). Later evidence showed that even seriously delinquent adolescents could be turned around through intensive, multi-system interventions (e.g., 6), although the high cost of these interventions limits their availability, and they are often introduced after arrests have been made and considerable harm done to youths, families, and society. If earlier, less-costly intervention could prevent later development of serious problems, this would be good news indeed.

Scott, Briskman, and O'Connor (7) test whether lower-cost treatment in childhood might in fact have benefits that carry over to later years, essentially operating as longterm prevention of antisocial behavior and traits. They present follow-up data from two of their group's earlier studies $(8,9)$ in which parents of young children (aged 3-7 in one study, 4-6 in the other) were randomized to a behavioral parent training program (4) or a control group. The initial sample in one study—severely antisocial and referred for treatment-was re-assessed at ages10-17; the initial sample in the second study-less severe but "high risk"—was re-assessed at ages 9-13.

Findings at follow-up were quite different for the two early intervention study samples. For the more severe clinic-referred sample, there were significant treatment vs. control group differences at long-term follow-up on measures of oppositional-defiant behavior, antisocial traits, parental warmth in an expressed emotion measure, parent reported child monitoring/supervision, and reading skill. The findings suggest that early 
intervention focused on parenting skills may have effects that extend well into adolescence. In contrast, follow-up analyses of the second study sample (high-risk but not clinically referred) showed no long-term effects of any kind. The contrast between these two sets of findings, and the rich body of detail provided by Scott et al., raise intriguing questions...

1. How firm are the long-term effects? The long-term effect on reading ability in the clinically referred sample was derived from a standardized performance measure with subjective factors minimized. However, all the positive findings on antisocial behavior and traits were derived from reports by the youths and parents who had participated in the earlier trial, were aware of which intervention they had received, and were presumably aware that this was a follow-up study by the same investigative team. By contrast, measures involving direct observation of parenting, and ratings by naïve informants (i.e., current teachers) showed no long-term effects. So, should we view the findings as solid evidence that early intervention can produce long-term effects on antisocial behavior and traits, or should we see the findings as subjective reports by former study participants perhaps motivated to report good news? The question cannot be answered definitively from the evidence currently available, but it does suggest the need for a further step.

2. Can early intervention affect the objective outcomes of greatest concern to society? A potentially valuable next step for Scott and colleagues will be to follow the research participants into the years when the most high-stakes adult outcomes can be assessed, and rather objectively—outcomes such as 
reduced criminal behavior, gainful employment, and success in interpersonal, romantic, and later parenting roles. Long-term benefits on outcomes like these could directly address questions about whether the findings transcend subjective reports, making the societal payoff for early intervention clear to all.

3. What determines whether early intervention will have long-term impact? If we assume, for the moment, the validity of the positive effects, a logical next question is what caused them. Juxtaposing the absence of long-term effects in the high-risk study sample with the multiple long-term effects found in the clinically referred study sample suggests several hypotheses, all warranting further study. At first blush, the differing findings for the two samples might seem to suggest that early intervention is more likely to produce long-term effects with more severely antisocial children than those who are less severe, a pattern consistent with at least some previous findings $(5,10,11)$. However, supplemental analyses by Scott et al. suggest that initial severity does not explain their findings, nor do between-study differences in ethnicity, maternal education, or housing. Discerning which factors did make a difference may be difficult in part because the two study follow-ups differed in numerous ways; for example, follow-up in the severe and referred sample extended to age 17 , potentially permitting more adolescent variability in outcomes (and thus more opportunity to detect treatment vs. control differences) than in the follow-up with the high-risk sample, which topped out at age 13. Scott et al. suggest that differences between long-term findings of the two studies may reflect (a) larger initial intervention effects for the clinic-referred sample, which 
were thus more likely to be sustained over time, (b) higher motivation by parents of children for whom treatment was being sought, and (c) regression to the mean on antisocial behavior by the high-risk community control group. These three differences, common in treatment versus prevention study comparisons, fit the hypothesis that treatment trials with referred children are more likely to produce lasting effects than prevention trials with high-risk youngsters who are not clinically referred. Verifying this or other hypothesis in future studies could help policy-makers determine which early intervention investments might be most likely to maximize long-term societal benefit.

4. What if there were no long-term effects? Scott et al have appropriately focused on the question of long-term benefit, and that benefit may turn out to be quite real. However, we should not forget that short term effects alone can mean a great deal to families and to society. Both parents and their children benefit when parents learn to devote quality time to their children, give instructions in ways that are clear and clearly understood, and reward their children with attention and praise for good behavior. Both children and parents benefit when children learn to attend to their parents, follow adult instructions, obey rules, and behave prosocially with siblings and peers. The more such parent and child behavior flourishes and spreads, the more the social systems involving the parent and child benefit. These effects may all be "short-term" benefits of effective parenting interventions like those used by Scott et al., but the benefit to society can be real and potentially quite broad, 
even if they do not last for many years. If the effects also leave a legacy that lasts into adolescence and beyond, that would be icing on the cake.

In their engaging and thoughtful article, Scott et al. raise important questions about the potential legacy effects of high-quality interventions for parents of young children. The findings answer some of these questions and highlight other questions for the days ahead. In both respects, the authors have made a valuable contribution.

\section{References}

1. Patterson GR, Ray RS, Shaw DA: Direct intervention in families of deviant children. Oregon Research Institute Research Bulletin 1968; 8: 1-11

2. Zisser A, Eyberg SM: (2010). Parent-child interaction therapy and the treatment of disruptive behavior disorders, in Evidence-based Psychotherapies for Children and Adolescents ( $2^{\text {nd }}$ edition). Edited by JR Weisz, AE Kazdin. New York, Guilford Press, 2010, pp 179-193

3. Kazdin AE: Parent management training: evidence, outcomes, and issues. J Am Academy Child and Adolescent Psychiatry 1997; 36: 1349-1356

4. Webster-Stratton C, Reid J: The Incredible Years parents, teachers, and children's training series: A multifaceted treatment approach for young children with conduct problems, in Evidence-based Psychotherapies for Children and Adolescents ( $2^{\text {nd }}$ edition). Edited by JR Weisz, AE Kazdin. New York, Guilford Press, 2010, pp 194-210 
5. Weisz JR, Ng MN, Rutt C, Lau N, Masland SA: Psychotherapy for children and adolescents, in Bergin and Garfield's Handbook of Psychotherapy and Behavior Change ( $6^{\text {th }}$ edition). Edited by Lambert MJ. New York, John Wiley \& Sons, 2013, pp 541-586

6. Henggeler SW, Schoenwald SK, Borduin CM, Rowland MD, Cunningham PB: Multisystemic treatment of antisocial behavior in children and adolescents. New York, Guilford Press, 1998

7. Scott S, Briskman J, O'Connor T: Early prevention of antisocial personality: long-term follow-up of two randomized controlled trials comparing indicated and selective approaches. Am J Psychiatry in press

8. Scott S, Spender Q, Doolan M, Jacobs B, Aspland H: Multicentre controlled trial of parenting groups for childhood antisocial behavior in clinical practice. BMJ 2001; 323: 194-197

9. Scott S, Sylva K, Doolan M, Price J, Jacobs B, Crook C, Landau S: Randomized controlled trial of parent groups for child antisocial behavior targeting multiple risk factors: the SPOKES project. J Child Psychology Psychiatry 2010; 51: 48-57

10. Conduct Problems Prevention Research Group: The effects of the Fast Track preventive intervention on the development of conduct disorder across childhood. Child Development 2011; 82: 331-345

11. Weisz JR: Psychotherapy for children and adolescents: Evidence-based treatments and case examples. Cambridge, UK, Cambridge University Press, 2004 